\title{
ANALISIS OPTIMALISASI INTENSITAS PENCAHAYAAN BUATAN TERHADAP EFISIENSI KERJA PADA PENJAHIT DI PASAR WONOMULYO
}

\author{
Ahmad Rifai ${ }^{1}$ \\ ${ }^{1)}$ Prodi S1 Kesehatan Masyarakat STIKes Bina Bangsa, Majene, Sulawesi Barat \\ E-mail: ahmadrifai.mufri@gmail.com
}

\begin{abstract}
ABSTRAK
Pencahayaan merupakan bagian penting dari bangunan dalam menunjang kenyamanan fisik dan fisiologi tenaga kerja dalam melaksanakan pekerjaannya menjadi lebih efisien. Intensitas pencahayaan buatan yang terlalu tinggi atau terlalu rendah akan menyebabkan masalah terhadap kesehatan.Tujuan penelitian untuk menggambarkan dan menganalisis optimalisasi intensitas pencahayaan buatan terhadap efisiensi kerja pada penjahit di pasar Wonomulyo.

Jenis penelitian yang digunakan adalah penelitian kualitatif dengan pendekatan fenomenologi.Subyek dalam penelitian sebanyak3 informan yang hanya menggunakan pencahayaan buatan dalam melakukan pekerjaannya dan ditentukan dengan teknik purposive sampling berdasarkan kriteria yang telah ditetapkan oleh peneliti.Setelah data terkumpul, selanjutnya dilakukan triangulasi yang bertujuan untuk mendapatkan data yang valid dan reliable. Triangulasi sumber yaitu penelitian mewawancarai secara semiterstruktur dengan menggali informasi mendetail subjek penelitian dan dokumentasi.Teknik analisis menggunakan teknik Miles dan Huberman yaitu reduksi data, penyajian data, dan verifikasi data.Hasil penelitian menyatakan rata-rata pengukuran intensitas pencahayaan pada ruang kerja tidak ada memenuhi syarat dengan pengukuran pagi pukul 08.30 bernilai 51,5 lux, siang pukul 13.00 bernilai 103,6 lux, sore pukul 16.40 bernilai 63 lux dengan standar 200 lux. Sedangkan untuk pencahayaan terhadap meja jahit (bidang kerja) rata-rata pada meja jahit 1 , meja jahit 2 dan meja jahit 3 yang diukur pada pagi, siang, sore hari ternyata hanya meja jahit 1 pada waktu siang pukul 13.00 yang optimal pencahayaannya dengan nilai 301 lux.Meja jahit 1 dihuni oleh (P1) yang hasil kerjanya lebih efisien karena dipengaruhi juga dengan umur pekerja.

Kesimpulan dari hasil penelitian yaitu intensitas pencahayaan buatan terhadap pekerja penjahitdi pasar Wonomulyo rata-rata tidak optimal dan kurang efisien. Sarannya untuk lebih memperhatikan penempatan para pekerja yang membutuhkan ketelitian dan ruang kerja kecil padat harus disiasati dengan mendesain penataan ruang secara tepat.
\end{abstract}

Kata Kunci:Optimal, Intensitas Pencahayaan Buatan, Efisiensi Keja.

\section{PENDAHULUAN}

Pencahayaan merupakan bagian penting dari sebuah bangunan dalam menunjang kenyamanan fisik dan fisiologi tenaga kerja dalam melaksanakan pekerjaannya menjadi lebih efisien. Tingkat intensitas pencahayaan di tempat kerja harus diperhatikan, usahakan sesuai dengan standar yang telah ditentukan. Intensitas pencahayaan yang kurang atau di bawah standar (terlalu sedikit cahaya) akan dapat menyebabkan masalah terhadap daya pandang dan terjadi kelelahan mata. Di lain pihak, intensitas penerangan yang 
terlalu tinggi juga akan dapat menyebabkan kesilauan dan cahaya pantulan secara berlebihan, menyebabkan mata mudah lelah, daya pandang cepat menurun. Pencahayaan yang tidak baik akan menimbulkan terjadinya stres pada penglihatan. Stres pada penglihatan ini bisa menimbulkan dua tipe kelelahan yaitu kelelahan mata dan kelelahan syaraf atau visual and nenlous fatique (Imansyah, 2008)

Penentuan kebutuhan pencahayaan tergantung pada pekerjaannya. Ruang yang telah dirancang tidak dapat memenuhi fungsinya dengan baik apabila tidak disediakan akses pencahayaan. Oleh sebab itu tingkat pencahayaan perlu diatur untuk menghasilkan kesesuaian kebutuhan penglihatan di dalam ruang berdasarkan jenis aktivitas (Santosa dalam Puspa 2008).

Beberapa penelitian membuktikan bahwa tingkat pencahayaan yang tepat dan disesuaikan dengan pekerjaan akan berdampak pada efisiensi kerja. Pada tahun 2008 telah dilakukan penelitian hubungan pencahayaan dengan keluhan kelelahan mata pada pekerja jasa menjahit di pasar Tomang Barat Jakarta Barat dengan hasil ada hubungan pencahayaan dengan keluhan kelelahan mata yang mempunyai hubungan sangat signifikan. Pencahayaan sangat berpengaruh terhadap terjadinya keluhan kelelahan mata, dalam artian semakin tinggi pencahayaan maka semakin rendah terjadinya keluhan kelelahan mata (Indah dkk, 2008).

\section{RANCANGAN PENELITIAN}

Jenis penelitian yang akan digunakan adalah penelitian kualitatif dengan pendekatan fenomenologi dan mempelajari fenomena tentang respon keberadaan manusia bertujuan untuk menjelaskan pengalaman seseorang dalam kehidupannya termasuk didalamnya adalah interaksi sosial yang dilakukannya (Wahab, A. 2013). Subyek dalam penelitian ini yaitu 3 informan yang hanya menggunakan pencahayaan buatan dalam melakukan pekerjaannya di pasar Wonomulyo, ditentukan dengan teknik purposive samplingsecara sengaja dipilih berdasarkan kriteria yang telah ditetapkan oleh peneliti sebagai berikut:

1. Pernah mendapatkan informasi tentang pencahayaan.

2. Bersedia menjadi informan

\section{HASIL}

Penelitian ini berlangsung selama sepuluh hari, yaitu mulai pada tanggal 19 hingga 28 juli 2017.

\section{Gambaran Karakteristik Informan Penelitian}

Penelitian ini menggunakan sumber informasi sebanyak tiga orang yang pernah mendapatkan informasi tentang pencahayaan, lalu bekerja sebagai penjahit dan waktu kerja mulai dari pagi hingga sore hari dengan jenis kelamin laki-laki serta memiliki perbedaan umur yang tentunya bersedia menjadi informan maka terpilihlah untuk menjadi informan. Gaya bahasa informan yaitu bahasa Indonesia dan terkadang berdialek jawa. Namun kutipan hasil penelitian akan disajikan dalam bentuk hasil yang telah melewati proses "editing" oleh peneliti.

a. Umur

Karakteristik informan berdasarkan umur diketahui bahwa informan berumur 27 - 40 tahun, terdiri atas umur 27 tahun 
1 orang, 30 tahun 1 orang, dan 40 tahun 1 orang.

b. Pekerjaan

Semua informan memiliki pekerjaan sebagai penjahit pakaian/celana di pasar Wonomulyo.

c. Waktu Kerja

Pekerjaan menjahit dilaksanakan mulai pukul 08.00 hingga pukul 17.00 WITA.

d. Kemampuan Menjahit

Setiap informan memiliki kemampuan yang berbeda-beda dalam menyelesaikan sebuah jahitan. Mulai dari tiga pakaian hingga tujuh dapat diselesaikan dalam waktu satu hari.Uraian di atas lebih rinci terdapat dalam Tabel 4.1 berikut:

Tabel 4.1.Gambaran karakteristik informan

\begin{tabular}{lllll}
\hline $\begin{array}{l}\text { Infor } \\
\text { man }\end{array}$ & Umur & Pekerjaan & $\begin{array}{l}\text { Waktu Kerja } \\
\text { (WITA) }\end{array}$ & $\begin{array}{l}\text { Kemampuan } \\
\text { Menjahit } \\
\text { (sehari) }\end{array}$ \\
\hline P1 & 27 Tahun & Penjahit & $08.00-1700$ & 5-7 Pakaian \\
P2 & 30 Tahun & Penjahit & $08.00-1700$ & 5 Pakaian \\
P3 & 40 Tahun & Penjahit & $08.00-1700$ & 3 Pakaian \\
\hline
\end{tabular}

Sumber: Data Primer, 2017

Hasil wawancara langsung yang dilakukan diketahui bahwa seluruh informan pernah mendapatkan informasi mengenai pencahayaan baik melalui bacaan, internet maupun orang lain.

\section{Gambaran Umum Kondisi Penjahit di Pasar Wonomulyo}

Letak penjahit pakaian ini berada di lantai dasar pasar Wonomulyo. Area kerja penjahit ini memiliki dimensi panjang ruang $3 \mathrm{~m}$ dan lebar ruang $28,5 \mathrm{~m}$, sehingga luas areanya menjadi $85,5 \mathrm{~m}^{2}$. Tenaga kerja dalam ruangan ini berjumlah tiga orang, setiap penjahit bertugas membuat pola sendiri, memotong bahan kain sendiri, mengobras bahan kain sendiri, serta bertanggung jawab dalam proses finishing (menyelesaikan/merapikan bagian-bagian pakaian/ celana pada akhir produksi masing-masing). Waktu kerja setiap hari dimulai pada pukul 08.00-17.00 WITA. Setiap penjahit melakukan pekerjaan mulai dari proses awal sebelum menjahit, mulai menjahit hingga selesainya sebuah jahitan tanpa ada shift atau rotasi kerja.

Alat-alat yang dimiliki di tempat menjahit ini antara lain adalah alat pemotong kain, empat unit meja jahit (tiga diantaranya sudah menggunakan tenaga dinamo/listrik dan yang satunya masih secara manual namun tidak terpakai), dua unit meja obras, dan satu unit setrika.

Secara garis besar deskripsi proses kerja yang dilakukan para penjahit di pasar wonomulyo dapat diuraikan sebagai berikut:

a. Pembuatan pola pada bahan kain sesuai dengan model pakaian yang telah ditentukan. Proses ini dilakukan diatas lantai karena ukuran bahan kain yang lebar dan tidak memungkinkan untuk dilakukan diatas meja.

b. Pemotongan bahan kain dilakukan di atas lantai agar lebih mudah dipotong sesuai dengan pola yang telah dibuat namun terkadang juga dilakukan diatas meja bila bahan kain tidak terlalu lebar. 
c. Pengobrasan bagian-bagian pakaian/celana yang telah dipotong sesuai polanya agar tepi kain tidak bertiras.

d. Penjahitan bagian-bagian pakaian/celana yang telah melalui proses pengobrasan.

e. Finishing, menyelesaikan atau merapikan pakaian/ celana pada akhir proses seperti menyetrika pakaian/ celana yang sudah dikerjakan dan lain-lain.

Dalam penelitian ini, peneliti lebih memfokuskan kepada pekerjaanpekerjaan yang membutuhkan ketelitian tinggi dan pencahayaan yang cukup seperti proses penjahitan bagianbagian pakaian/celana.

Tabel 4.2 Gambaran Umum Kondisi Ruang Kerja pada Penjahit di Pasar Wonomulyo

\begin{tabular}{|c|c|c|c|c|}
\hline No & $\begin{array}{l}\text { Kondisi } \\
\text { Ruang Kerja }\end{array}$ & Meja 1 & Meja 2 & Meja 3 \\
\hline 1 & Jenis Lampu & Fluorescent & Fluorescent & Fluorescent \\
\hline 2 & Kapasitas & $24 \mathrm{~W}$ & $24 \mathrm{~W}$ & $24 \mathrm{~W}$ \\
\hline 3 & $\begin{array}{l}\text { Daya Aliran } \\
\text { Listrik }\end{array}$ & \multicolumn{3}{|c|}{$\begin{array}{l}\text { Ketiga lampu memiliki aliran yang sama dari } \\
\text { PLN dengan daya } 900 \text { Volt }\end{array}$} \\
\hline 4 & Posisi Lampu & $\begin{array}{l}\text { Sebelah kiri } \\
\text { penjahit, } \\
\text { pada bagian } \\
\text { atas (langit- } \\
\text { langit) } \\
\text { sejajar } \\
\text { penjahit } \\
\text { meja } 1\end{array}$ & $\begin{array}{l}\text { Sebelah } \\
\text { kanan } \\
\text { penjahit, } \\
\text { pada bagian } \\
\text { atas yang } \\
\text { berada di } \\
\text { tengah- } \\
\text { tengah } \\
\text { antara meja } \\
2 \text { dan meja } \\
3\end{array}$ & $\begin{array}{l}\text { Berada pada } \\
\text { belakang penjahit } \\
\text {, bagian atas } \\
\text { (langit-langit) } \\
\text { antara meja } 3 \text { dan } \\
\text { meja } 2\end{array}$ \\
\hline 5 & Luas Ruangan & \multicolumn{3}{|c|}{$\begin{array}{l}\text { Ketiga meja jahit berada dalam } 1 \text { ruangan yang } \\
\text { sama yaitu } 85,5 \mathrm{~m}^{2}\end{array}$} \\
\hline 6 & $\begin{array}{l}\text { Warna } \\
\text { Lingkungan }\end{array}$ & \multicolumn{3}{|c|}{$\begin{array}{l}\text { Langit-langit berwarna putih, dinding berwarna } \\
\text { hijau daun dan lantai berwarna putih }\end{array}$} \\
\hline
\end{tabular}

\section{Sumber: Data Primer}

Kondisi ruang kerja akan memberikan pengaruh terhadap pencahayaan yang dipantulkan. Terutama pada sumber pencahayaan yang digunakan dan letaknya didalam suatu ruang kerja. Daya aliran listrik sangat berpengaruh terhadap pancaran sinar setiap lampu. Luas ruangan perlu diperhatikan agar pencahayaan yang diterima sesuai dengan kebutuhan, artinya tidak terlalu tinggi karena dapat menyebabkan kesilauan dan tidak terlalu rendah karena dapat menyebabkan mata bekerja keras yang dapat membuat mata rabun. Pemilihan warna ruangan harus sesuai apalagi untuk di ruang kerja, warna pada dinding memiliki pengaruh psikologi bagi manusia makanya harus tepat.

\section{Hasil Pengukuran Intensitas} Pencahayaan pada Lokasi Penjahit di Pasar Wonomulyo

Penelitian pengukuran pencahayaan pada lokasi penjahit di pasar Wonomulyo dilaksanakan selama tiga hari dan dalam sehari diukur pada tiga waktu yaitu mulai pagi pukul 08.30 WITA, siang pukul 13.00 WITA dan sore pukul 16.40 WITA untuk pengukuran pada meja jahit (bidang kerja) dan ruang kerja secara keseluruhan.

Tabel 4.3 Hasil Pengukuran Intensitas Pencahayaan Ruang Kerja di Lokasi

Los Penjahit di Pasar Wonomulyo Sumber: Hasil Analisis 


\begin{tabular}{|c|c|c|}
\hline $\begin{array}{c}\text { Waktu } \\
\text { Pengukuran } \\
\text { (JAM) }\end{array}$ & $\begin{array}{c}\text { Rata-Rata } \\
\text { Hasil } \\
\text { Pengukuran } \\
\text { Pencahayaan } \\
\text { Ruang Kerja } \\
\text { (Lux) } \\
\end{array}$ & $\begin{array}{l}\text { \% Terhadap } \\
\text { Standar } \\
(200 \text { Lux })\end{array}$ \\
\hline $\begin{array}{l}\text { Pagi } \\
(08.30)\end{array}$ & 51,5 & 25,75 \\
\hline $\begin{array}{l}\text { Siang } \\
(13.00)\end{array}$ & 103,6 & 51,8 \\
\hline $\begin{array}{c}\text { Sore } \\
(16.40)\end{array}$ & 63 & 31,5 \\
\hline
\end{tabular}

Berdasarkan Tabel 4.3 diperoleh rata-rata hasil pengukuran intensitas pencahayaan terhadap ruang kerja pada waktu pagi hari sebesar 51,5 lux dan jika diubah dalam \% terhadap standar 200 lux bernilai $25,75 \%$, selanjutnya pada waktu siang hari hasil rata-rata sebesar 103,6 lux dan diubah dalam \% terhadap standar 200 lux bernilai $51,8 \%$, kemudian pada waktu sore hari sebesar 63 lux dan diubah dalam \% terhadap standar 200 bernilai 31,5\%. Ini berarti bahwa pencahayaan pada ruang kerja penjahit di pasar Wonomulyo tidak optimal karena ratarata tidak mencapai standar, bahkan setelah diubah dalam bentuk persen (\%) nilainyapun tidak termasuk dalam kisaran batas yang dapat ditoleransi. Diketahui bahwa batas kisaran yang masih dapat ditoleransi pencahayaan pada ruang yaitu $80-90 \%$. Berdasarkan Tabel 4.3 hasil pengukuran rata-rata menunjukkan bahwa ruang kerja ini termasuk cukup gelap untuk digunakan sebagai ruang kerja yang membutuhkan ketelitian. Ruang kerja ini tidak optimal pencahayaannya karena warna dinding yang digunakan warna hijau daun. Diketahui bahwa warna hijau daun memiliki reflektan yang cukup rendah sebesar 20-25\%, karena menyerap sebagian pencahayaan dari lampu fluorescent pada los penjahit.

Tabel 4.4 Hasil Pengukuran Intensitas Pencahayaan Lampu fluorescent terhadap Meja Jahit (bidang kerja) pada Penjahit di

\begin{tabular}{cccc}
\multicolumn{4}{c}{ Pasar Wonomulyo } \\
$\begin{array}{c}\text { Waktu } \\
\text { Pengukuran }\end{array}$ & $\begin{array}{c}\text { Rata-rata } \\
\text { Meja Jahit 1 } \\
\text { (Lux) }\end{array}$ & $\begin{array}{c}\text { Rata-rata } \\
\text { Meja Jahit 2 } \\
\text { (Lux) }\end{array}$ & $\begin{array}{c}\text { Rata-rata } \\
\text { Meja Jahit 3 } \\
\text { (Lux) }\end{array}$ \\
\hline Pagi (08.30) & 105 & 55 & 67 \\
Siang (13.00) & 301 & 52,3 & 68,7 \\
Sore (16.40) & 81,7 & 50,3 & 64,7 \\
\hline
\end{tabular}

Sumber: Hasil Analisis, 2017

Berdasarkan Tabel 4.4 pengukuran intensitas pencahayaan lampu fluorescent terhadap meja jahit (bidang kerja) pada waktu pagi selama tiga hari diperoleh ratarata meja jahit satu sebesar 105 lux, meja jahit dua sebesar 55 lux, dan meja jahit tiga sebesar 67 lux. Ini menunjukkan bahwa tidak ada satupun meja jahit yang optimal intensitas pencahayaan pada waktu pagi hari.

Selanjutnya untuk pengukuran pada waktu siang hari diperoleh rata-rata meja jahit satu sebesar 301 lux, meja jahit dua sebesar 52,3 lux dan meja jahit tiga sebesar 68,7 lux. Ternyata terjadi perbedaan antara pengukuran diwaktu pagi, yaitu dari ketiga meja jahit sebelumnya tidak ada yang optimal, namun pada saat pengukuran untuk waktu siang hari meja jahit satu menjadi optimal intensitas pencahayaan. Pada meja jahit dua dan meja jahit tiga masih belum optimal pencahayan yang diterima dari lampu fluorescent, ini dipengaruhi oleh letak meja jahit dua dan meja jahit tiga kurang sesuai. Meja jahit dua menerima pencahayaan dari lampu fluorescent yang sama dengan meja jahit tiga, namun posisi meja jahit dua dan meja jahit tiga berbeda 
cara peletakannya. Informan (P2) yang menempati meja jahit dua menerima pencahayaan dari sebelah kanannya ketika melakukan pekerjaan menjahit sedangkan informan (P3) yang menempati meja jahit tiga menerima pencahayaan lampu fluorescent dari belakangnya. Padahal pekerjaan dalam menjahit harus menerima pencahayaan yang dekat dengan fokus kerjanya yaitu pada jarum mesin jahit. Ketika sumber pencahayaan berada di sebelah kanan atau jauh kebelakang, maka pencahayaan akan menimbulkan bayangan (shadow) dan dapat mengurangi intensitas pencahayaan yang diterima oleh para penjahit.

Kemudian pengukuran waktu sore hari diperoleh rata-rata meja jahit satu sebesar 81,7 lux, meja jahit dua sebesar 50,3 lux dan meja jahit tiga sebesar 64,7 lux. Ini menunjukkan bahwa tidak ada satupun intensitas pencahayaan yang optimal pada saat waktu sore. Hal tersebut dipengaruhi oleh faktor lingkungan yang sudah mulai gelap kembali karena banyak los tertutup. Kemudian dinding-dinding yang banyak digantungi pakaian-pakaian hasil jahitan, lantai tertutup sisa-sisa kain, meja jahit (bidang kerja) juga terdapat sisa-sisa kain yang tanpa disadari penjahit dapat berpengaruh dalam penerimaan pencahayaan.

\section{PEMBAHASAN}

Berdasarkan hasil informasi yang telah diperoleh mulai dari observasi, wawancara, dan dokumentasi. Pengukuran intensitas pencahayaan di los penjahit dibagi menjadi tiga waktu yaitu pagi, siang dan sore. Sedangkan pengukuran pencahayaan untuk melihat optimalisasinya dibagi menjadi dua yaitu pencahayaan pada meja jahit (bidang kerja) dan pencahayaan ruang kerja secara keseluruhan. Berikut akan dijelaskan oleh peneliti mengapa intensitas pencahayaan pada los penjahit pasar Wonomulyo secara keseluruhan belum optimal.

Berdasarkan Tabel 4.1 menunjukkan bahwa terdapat tiga informan yang dijadikan sumber penggalian informasi oleh peneliti dan memiliki umur yang berbeda-beda serta memiliki kemampuan berbeda pula dalam menghasilkan pakaian/celana. Berdasarkan Tabel 4.2 dapat diketahui gambaran umum kondisi ruang kerja pada penjahit di pasar Wonomulyo. Untuk lebih jelasnya akan dipaparkan oleh penulis, mulai dari jenis lampu yang digunakan adalah lampu TL (fluorescent) dengan kapasitas $24 \mathrm{~W}$ dan daya aliran listrik berasal dari PLN (Perusahaan Listrik Negara) berdaya 900 Volt. Lampu dengan kapasitas $24 \mathrm{~W}$ untuk ruangan yang berukuran 85,5 $\mathrm{m}^{2}$ sebenarnya dapat mencapai pencahayaan ruang yang optimal apabila desainnya tepat sasaran.

Hanya saja peletakan benda-benda serta jarak sumber pencahayaan harus sesuai dan pemilihan warna diding juga sangat berpengaruh. Pada los penjahit pasar Wonomulyo warna langit-langit dan lantai sudah tepat karena memilih warna putih yang mampu memberikan reflektan sebesar $100 \%$. Namun pada warna dinding untuk digunakan sebagai ruang kerja kurang tepat. Warna yang digunakan adalah warna hijau, pada dasarnya warna hijau memiliki beberapa tingkatan mulai yang nampak terang hingga agak gelap. Warna hijau seperti hijau terang dan hijau lime lebih cocok digunakan dalam ruang kerja dibanding hijau rumput, hijau daun maupun hijau yang lainnya. 
Pada saat melakukan wawancara ternyata informan lebih senang dengan warna hijau, makanya disarakankan untuk mengganti warna dinding hijau yang lebih terang agar pencahayaan ruangan dapat mencapai keoptimalan. Berdasarkan Tabel 4.3 diperoleh rata-rata hasil pengukuran intensitas pencahayaan terhadap ruang kerja pada waktu pagi, siang dan sore hari tidak ada satupun yang optimal. Hal tersebut dipengaruhi oleh faktor lingkungan yang telah dipaparkan sebelumnya. Jadi, agar pencahayaan ruang dapat menjadi optimal sebaiknya faktorfaktor tersebut senantiasa diperhatikan sekecil apapun itu. Seperti warna pada dinding sebaiknya segera diubah menjadi warna yang lebih terang dan sehubungan informan sangat menyukai warna hijau maka dapat mengubahnya menjadi warna hijau terang agar reflektan yang dihasilkan lebih besar daripada warna hijau daun yang digunakan pada saat penelitian.

Sumber pencahayaan atau lampu TL dibersihkan agar tidak terdapat sarang laba-laba di area tersebut. Diketahui bahwa ruangan ini cukup padat dengan mesin jahit, meja tempat setrika, dan rak tempat pakaian. Ruangan yang tidak begitu luas dan terdapat banyak barang didalamnya harus disiasati agar tidak mengurangi pencahayaan ruang kerja. Tempat menggantung pakaian hasil jahitan juga harus berada pada area yang tidak akan menutupi sebagian besar sumber pencahayaan. Posisi lampu pada ruang kerja harus diperhatikan jaraknya terhadap meja jahit (bidang kerja) agar lebih optimal pencahayaannya.

Apabila letak meja jahit sudah tidak bisa diubah, maka sumber pencahayaan harus ditambah pada setiap meja jahit. Artinya pencahayaan untuk meja jahit dua dan meja jahit tiga masing-masing memiliki sumber pencahayaan tersendiri pada bagian kiri penjahit, dengan demikian intensitas yang akan diperoleh meja jahit dua dan meja jahit tiga dapat menjadi optimal seperti meja jahit satu pada waktu siang. Untuk memperoleh intensitas pencahayaan pada ruang kerja dan bidang kerja pada semua waktu, baik itu pada pagi, siang maupun sore hari, maka sumber pencahayaan yang digunakan untuk ruang kerja harus lebih tinggi pencahayaannya dibanding bidang kerja.

Sumber pencahayaan pada ruang kerja harus lebih terang karena lebih luas fokus pancaran sinarnya. Pencahayaan ruang kerja harus sesuai karena memiliki pengaruh yang cukup penting terhadap intensitas pencahayaan yang akan diterima oleh para pekerja dan dapat berpengaruh terhadap efisiensi kerja. Untuk lebih jelasnya peneliti akan mengkajinya sebagai berikut: sumber pencahayaan buatan yang digunakan untuk menerangi bidang kerja ini adalah 3 unit lampu fluorescent (TL) dengan kapasitas masing-masing $24 \mathrm{~W}$ daya aliran listrik 900 volt.

Lampu TL yang pertama di pasang tepat di langit-langit bagian dalam los penjahit, lampu TL yang ke dua dipasang pada pojok atas sejajar dengan mesin jahit, lampu TL yang ketiga berada pada pertengahan atas pintu los yang tepat diantara dua meja mesin jahit. Telah dipaparkan sebelumnya bahwa waktu kerja dilaksanakan mulai dari pagi hingga sore hari dan tidak ada waktu malam hari.Meskipun waktu kerja informan memiliki peluang yang besar untuk mendapatkan bantuan pencahayaan alami, akan tetapi lokasi penelitian terletak 
ditengah pasar dengan bangunan yang saling berimpitan dengan penjahit lainnya dan diantarai oleh atap seng yang tertutup rapat dan tidak transparan.

Dengan demikian pencahayaan buatan sangat berperan penting dalam penyelesaian pekerjaan informan. Selanjutnya warna lingkungan kerja, bidang permukaan kerja diarea los penjahit pasar Wonomulyo berwarna putih bertekstur halus dengan panjang $25 \mathrm{~cm}$ dan lebar $25 \mathrm{~cm}$. Dinding disekitar area kerja tersebut berwarna hijau daun. Langit-langit diarea kerja ini berwarna putih dan bertekstur halus dengan panjang $50 \mathrm{~cm}$ dan lebar $50 \mathrm{~cm}$. Pada penggunaan warna putih untuk lantai dan langit-langit sudah tepat, karena bahan warna putih dapat memberikan reflektan sebesar $100 \%$. Warna hijau daun pada dinding dapat memberikan reflektan sebesar 20-25\%.

Secara keseluruhan pemilihan warna ruang sudah lumayan bagus, dengan warna ringan seperti warna putih pada lantai akan memantulkan lebih banyak cahaya daripada lantai yang berwarna gelap dan bertekstur serta pemilihan warna hijau pada dinding dapat memberikan efek psikologis seperti penyegaran mata dan pikiran, keseimbangan pikiran, juga membawa kedamaian. Saat mata melihat sesuatu yang hijau, mata tidak perlu penyesuaian apapun, makanya kita terasa nyaman dan tenang ketika melihatnya. Hijau dianggap warna yang menenangkan dan santai, cocok sekali untuk dilihat bagi orang yang sedang tegang atau butuh menyeimbangkan emosi, menciptakan keterbukaan antara manusia.

Namun warna hijau memiliki beberapa tampilan warna yang berbeda, ada warna hijau yang mampu memberikan reflektan
$50-55 \%$ dan ada juga yang hanya memberikan reflektan 20-25\%. Pemilihan warna hijau yang berada di los penjahit ini adalah warna hijau daun dan termasuk pada reflektan 20-25\%. Inilah yang membuat pencahayaan ruangan kurang dipantulkan, dengan kata lain bahwa pencahayaannya diserap makanya intensitas pencahayaan ruang pada penjahit di pasar Wonomulyo tidak ada mencapai titik optimal.

Kemudian ketinggian langit-langit, ketinggian langit-langit yang diukur dari lantai secara tegak lurus adalah $3 \mathrm{~m}$, ini berarti sumber cahaya yang berada dalam ruangan terpasang tepat pada langit-langit berjarak $3 \mathrm{~m}$ untuk menerangi ruangan. Sedangkan jarak antara langit-langit dengan sumber cahaya yang di pojok dan di tengah-tengah pintu adalah $0,7 \mathrm{~m}$. Jarak antara meja jahit dengan sumber cahaya pada pojok dan pertengahan pintu adalah 1,5 m. Dari ketiga sumber cahaya lampu fluorescent (TL) seharusnya lampu fluorescent (TL) yang dipasang pada langit-langit dalam ruang lebih terang dibanding lampu fluorescent (TL) yang dipasang dekat dengan meja kerja.

Berdasarkan klasifikasi lantai, dan langitlangit sebagai penunjang pencahayaan, secara umum dapat dikatakan telah sesuai. Hal ini sesuai dengan Keputusan Direktorat Jenderal PPM dan PLP sebagaimana dinyatakan bahwa: pertama lantai terbuat dari bahan yang kuat, kedap air, tidak licin, tidak retak dan mudah dibersihkan. Kedua, dinding berwarna terang dan bersih, permukaan halus, tidak bergelombang atau bergerigi dan retakretak. Ketiga, langit-langit berwarna terang dan bersih, bebas dari sarang laba-laba, terbuat dari bahan yang kuat serta tinggi 
berkisar antara 2,70 - 3,30 m diatas lantai (Sutanto dalam Indah 2013).

Berdasarkan pada Tabel 4.4 bahwa hasil pengukuran rata-rata lampu fluorescentterhadap meja jahit (bidang kerja) pada waktu pagi mulai dari meja jahit satu, meja jahit dua bahkan meja jahit tiga tidak ada satupun yang optimal intensitas pencahayaanya. Padahal pengukuran yang dilakukan tidak hanya sekali, namun pengukuran dilakukan sebanyak tiga kali dalam tiga hari dan hasilnya rata-rata tetap sama yaitu tidak memenuhi standar apalagi untuk mencapai optimalisasi intensitas pencahayaan. Ini disebabkan karena adanya hubungan dengan pencahayaan ruang kerja yang telah dipaparkan sebelumnya. Diketahui bahwa pada waktu pagi hari lingkungan kerja yang ada disekitar masih gelap makanya kurang mampu memantulkan pencahayaannya. Ini diperkuat dengan pernyataan informan (P1) "ketika hari masih pagi, rata-rata los yang ada di pasar belum terbuka".

Pada lembaran sebelumnya sudah dijelaskan letak tempat menjahit ini berada dibagian tengah pasar dan hanya mengandalkan pencahayaan buatan sebanyak tiga, dua diantaranya untuk sumber pencahayaan fokus pada meja jahit (bidang kerja) dan satunya untuk pencahayaan ruang kerja. Ketika tidak ada pencahayaan yang berasal dari depan atau samping los maka pencahayaan yang ada pada los (ruang) kurang mampu memantulkan cahayanya. Itulah yang membuat intensitas yang diterima pada pagi hari tidak optimal karena pencahayaan akan memiliki pantulan yang besar ketika bertemu dengan permukaan atau warna yang terang disekelilingnya, sedangkan untuk warna gelap apabila bertemu pencahayaan bukannya dipantulkan melainkan diserap.

Terlebih lagi jika ditambah dengan pakaian-pakaian yang bergantungan di dinding-dinding dan beberapa yang sangat dekat dengan sumber pencahayaan, tanpa mereka sadari dapat menghalangi pantulan pencahayaan yang diperoleh. Selanjutnya dilakukan lagi pengukuran pada siang hari yang hasil rata-ratanya untuk pencahayaan lampu fluorescent terhadap meja jahit (bidang kerja) ternyata hanya meja jahit satu yang memenuhi standar dan mencapai optimalisasi intensitas pencahayaan.Sedangkan untuk pencahayaan pada meja jahit dua dan meja jahit tiga belum mencapai titik optimal.

Meja jahit satu dapat dikatakan optimal pencahayaannya karena rata-rata dari hasil pengukuran melebihi standar yang telah ditentukan dan tidak menimbulkan kesilauan terhadap informan (P1) dan hasil kerjanya juga lebih efisien dibanding informan yang lain. Ini diperkuat dengan penyataan Informan (P1) bahwa "Secara umum Saya dapat menyelesaikan mulai dari kisaran lima hingga tujuh pakaian, namun apabila semuanya adalah pakaian dinas maka Saya hanya mampu menyelesaikan sebanyak lima. Tapi, terkhusus pakaian seragam sekolah, Saya mampu menyelesaikan mulai dari kisaran tujuh hingga sembilan dalam sehari”. Informan (P1) juga tidak kesulitan memasukkan benang ke dalam jarum jahit dan matanya tidak sakit. Intensitas pencahayaan yang diterima oleh meja jahit (bidang kerja) satu untuk informan (P1) mencapai optimal juga dipengaruhi oleh beberapa faktor lingkungan seperti penataan ruang, letak fokus meja jahit 
(bidang kerja), jenis lampu dan jarak sumber pencahayaannya.

Meja jahit satu berada dipojok dengan sumber pencahayaan yang diterima bidang kerja ini berasal dari satu unit lampu fluorescent berdaya $24 \mathrm{~W}$ yang berada pada bagian atas hampir sejajar dengan kepala bagian kiri penjahit. Jarak antara lampu fluorescent dengan fokus kerja adalah 1,5 m.Fokus bidang kerja meja jahit satu dihuni oleh informan pertama (P1) yang berusia 27 tahun. Pada bidang kerja ini intensitas pencahayaannya termasuk optimal dan memberikan pengaruh terhadap efisiensi kerja pada penjahit. Ini diperkuat dengan hasil wawancara mendalam pada ketiga informan. Dari ketiga informan dalam menyelesaikan sebuah jahitan memiliki kemampuan yang berbeda-beda.

Sebenarnya berdasarkan pengamatan peneliti selama beberapa hari dengan waktu-waktu yang ditetapkan untuk diakukan pengukuran, pada siang hari lebih banyak mendapatkan pantulan cahaya. Seperti yang telah dijelaskan mengenai penataan ruang, ternyata itu memang betul- betul berpengaruh. Kondisi ruangan (los penjahit) diwaktu siang banyak menerima pantuan pencahayaan yang berasal dari lampu para tetangga los terdekat, serta dinding-dinding yang belum terhalang oleh pakaian-pakaian yang telah di jahit, lantai yang masih lumayan bersih, dan beberapa pakaian telah dirapikan disusun pada rak.

Dinding yang cerah memberikan pantulan pencahayaan yang lebih besar daripada dinding yang tertutup dengan pakaian berwarna gelap serta lantai dan langitlangitnya yang berwarna putih. Sedangkan meja jahit dua dan meja jahit tiga tidak optimal pencahayaannya, seharusnya satu lampu fluorescent fokus pada satu bidang kerja, namun untuk bidang kerja dua dan tiga ini sumbernya itu dibagi dua, dan letaknya pun yang harusnya dikiri malah dikanan. Makanya tidak optimal pencahayaan yang diterima .

Pengukuran yang telah dilaksanakan selama tiga hari pada waktu sore tidak mencapai optimalisasi intensitas pencahayaan. Dan ini dapat mempengaruhi efisiensi kerja para penjahit. Lebih jelasnyabahwa berdasarkan pencahayaan yang cukup untuk pekerjaan membedabedakan barang-barang kecil yang agak teliti seperti menjahit tekstil atau kulit yang berwarna muda harus paling sedikit mempunyai kekuatan 200 lux (suma'mur, 2014).

Kondisi ruang los penjahit pada sore hari cukup gelap jika berdasarkan standar intensitas pencahayaan, ini disebabkan hasil dari potongan-potongan kain/ sisasisa kain yang tidak digunakan lagi berserakan di lantai. Mulai dari pagi melakukan pekerjaan menjahit tentunya akan menghasilkan beberapa pakaian dan juga beberapa sampah. Apalagi ruangannya tidak terlalu luas dan di huni sebanyak tiga orang penjahit.

Dengan melakukan kegiatan menjahit tentu menghasilkan pakaian yang beberapa diantaranya harus disetrika dahulu lau digantung. Kegiatan seperti ini membuat sebagian besar permukaan dinding tertutupi/ terhalangi oleh pakaian dan bahkan beberapa diantaranya dekat dengan sumber pencahayaan yang hampir menutupi lampu flourescent. Ditambah lagi dengan adanya sisa kain pada bidang 
kerja (meja jahit) yang kurang diperhatikan para penjahit di los tersebut.

Bidang kerja, sumber pencahayaan, lantai dan dinding semakin sulit memantulkan cahayanya karena dihalangi beberapa pakaian dan sisa-sisa kain. Inilah yang membuat pencahayaan yang diterima oleh para penjahit mengalami penurunan, karena tidak selamanya baju-baju yang digantung berwarna terang, sehingga cahaya tidak dipantulkan secara optimal, dan juga tetangga los terdekat sudah mulai banyak yang tertutup. Makanya hasil pengukuran intensitas pencahayaan pada waktu sore hari ini jauh dari kata optimal.

Hasil pengukuran yang dilakukan ternyata memiliki keterkaitan antara informan, sumber pencahayaan, pencahayaan ruang kerja, meja jahit (bidang kerja). Setiap informan memiliki umur yang berbedabeda, dan ternyata umur ini memberikan pengaruh terhadap efisiennya suatu pekerjaan terlebih lagi jika terkombinasi dengan pencahayaan yang optimal. Semakin muda umur Informan dan didukung oleh letak sumber pencahayaan terhadap meja jahit (bidang kerja) maka semakin banyak pula pakaian yang mampu dihasilkan. Sebaliknya semakin tua umur informan yang disertai letak meja jahit kurang tepat maka kemampuan menghasilkan pakaian hanya sedikit.

Umur para penjahit yang berbeda ini harus disiasati dengan cara mendesain ulang tempat kerja mereka, karena intensitas pencahayaan ruang kerja dan bidang kerja sangat berpengaruh terhadap efisiensi kerja para penjahit. Jadi, meskipun umurnya sudah tidak muda lagi namun dengan optimalnya intensitas pencahayaan maka dapat membantu atau meningkatkan hasil kerjanya. Terlebih lagi pada penjahit yang masih muda, akan lebih efisien lagi dalam melaksanakan pekerjaannya. Tidak hanya itu saja, ketika pencahayaan yang diterima kurang baik dalam waktu yang lama maka dapat berdampak pada kesehatan para pekerja. Itulah sebabnya sejak dini harus diperbaiki dari awal sebelum terjadi halhal yang tidak diinginkan.

\section{KESIMPILAN DAN SARAN}

\section{A. Kesimpulan}

Berdasarkan hasil dan pembahasan yang telah dipaparkan sebelumnya, di peroleh kesimpulan sebagai berikut:

1. Penggunaan lampu fluorescent, pemilihan warna dinding, warna lantai, langit-langit yang cerah, penataan ruang seperti jarak antara sumber pencahayaan terhadap meja jahit (bidang kerja), dan sumber pencahayaan terhadap ruang kerja keseluruhan serta umur pekerja berperan penting dalam pencapaian optimalisasi intensitas pencahayaan terhadap efisiensi kerja penjahit.

2. Dengan menata kondisi ruang dan memperhatikan kebersihan sumber pencahayaan dapat menjadikan semua pencahayaan terhadap meja jahit (bidang kerja) mencapai nilai standar yaitu 200 lux. Intensitas pencahayaan pada ruang kerja dan meja jahit (bidang kerja) di pasar Wonomulyo rata-rata belum optimal.

\section{B. Saran}

Adapun beberapa saran yang diajukan dalam penelitian ini diantaranya sebagai berikut:

1. Pihak pemerintah yang terkait dalam hal ini yaitu kepala pasar dalam membuat perencanaan lokasi maupun desainletak pekerja yang 
membutuhkan ketelitian sebaiknya menempatkan pada lokasi yang dapat menerima pencahayaan alamiahagar dapat dikombinasikan dengan pencahayaan buatan untuk mencapai optimalisasi intensitas pencahayaan.

2. Untuk para penjahit sebaiknya mampu menyiasati ruang kerja yang cukup kecil karena dihuni lebih dari satu pekerja dan alat serta bahan, kemudian memperhatikan faktor penunjang tercapainya intensitas pencahayaan optimal agar kerjanya efisien dan memperoleh keuntungan lebih.

\section{DAFTAR PUSTAKA}

Ari, 2017. Optimalisasi Pencahayaan Alam i dalam Efisiensi Energi di Perpu stakaan UGM. Academia, (online ), http://www.academia.edu/153 64108/optimalisasi-pencahayaanalami-dalam-efisiensi-energi-diperpustakaan_UGM, diakses 23 Juni 2017).

Azuma, F. 2014. Pengaruh Intensitas Penerangan Terhadap Kelelahan Mata pada Karyawan Bagian Produksi Pelintingan Manual di PT DJITOE INDONESIA Tobako. Skripsi. Surakarta: Program Studi Kesehatan Masyarakat Fakultas Ilmu Kesehatan Universitas Muhammadiyah. (online), (http://www.surakarta.ac.id, diakses 23 Juni 2017)

Firmansyah, 2010. Pengaruh Intensitas Penerangan Terhadap Kelelahan Mata Pada Tenaga Keja Di Bagian Pengepakan PT. IKAPHARMINDO PUTRAMAS
Jakarta Timur. Skripsi. Surakarta: Fakultas Kedokteran UNS.

Indah dkk, 2013. Analisa Pengaruh Pencahayaan Terhadap Kelelahan Mata Operator Di Ruang Kntrol PT. XYZ,. Infokes.

Junaedi, 2014. Analisis Kesalahan Dalam Menyelesaikan Soal Cerita Sistem Persamaan Linear Dua Variabel Ditinjau Dari Kemampuan Awal Pada Siswa Kelas VIII SMP Negeri 1 Pamboang. Tesis. Makassar : Program Pasca Sarjana Universitas Negeri Makassar.

Kurniawan. 2017. Apa Itu Menjahit dan Manfaat Manfaat. Belajar Menjahit

Otodidak, (online),(http://belajar menjahitotododak.blogspot.co.id/ 2015/08/apa-itu-menjahit-danmanfaat-html?m=1, diakses 24 Juni 2017).

Lupita. 2017. Efisiensi Sistem Kerja. Aniat if, (online), http://aniatif.blogspot .co.id/2013/11/efisiensi-sistem-

kerja6559.html?m=1, diakses 24 Juni 2017).

Puspa, 2008. Hubungan Intensitas Pencahayaan dengan Keluhan Kelelahan Mata pada Penjahit Sektor Usaha Informal CV Wahyu Langgeng. Jakarta: (online), (http://www.jakarta.ac.id, diakses 23 Juni 2017)

Sedarmayanti, 2009. Sumberdaya manusia dan produktivitas keja. Bandung: CV.Mandar Maju.

Silalahi, 2007. Studi Tentang Ilmu Administrasi. Study, (online),studi-tentang-ilmu- 
administrasi.56781.html?m=1, diakses 24 Juni 2017).

Soemirat Juli, 2004. Kesehatan Lingkungan. Yogyakarta : Gadjah Mada University Press.

Soeripto,M.2008. Higiene Industri. Jakarta: Fakultas Kedokteran Universitas Indonesia.

Soewarno, 1990. Pengantar Studi Ilmu Administrasi dan Manajemen. Study, (online),pengantar-studiilmu-administrasi-danmanajemen.57621.html? $\mathrm{m}=1$, diakses 24 Juni 2017).

Suma'mur, 2014. Higiene Perusahaan dan Kesehatan Kerja. Jakarta: Sagung Seto.

Tarwaka, 2010. Ergonomi Industri. Edisi Pertama Cetakan Pertama. Surakarta: Harapan Offset.

Undang-undang No 23 Tahun 1992 Tentang Kesehatan. Jakarta: Keppres.
Utarini,A. 2012. Metode Penelitian Kualitatif. Magister Perilaku dan Promosi Kesehatan Program Studi Ilmu Kesehatan Masyarakat Sekolah Pascasarjana Universitas Gadja Mada Yogyakarta.

Wahab, A. 2013. Pengantar Riset Bidang Kesehatan, Kebidanan, dan Kepe rawat-an. Yogyakarta: Kaukaba.

Wibiyanti, 2008. Analisis Pencahayaan di Apras Industri Kecil Pakaian Olahraga. Skripsi. Jakarta: (online), (http://124128-S-5265Kajian-pencahayaan-Analisis1.pdf,diakses 23 Juni 2017).

Wiki. 2017. Menjahit. Wikipedia, (online) ,(http://id.m.wikipedia.org/wiki/ menjahit, diakses 24 Juni 2017).

Yuliani, 2017. Produktifitas Evektivitas Ef isiensi. Air Ku Saja, (online), (htt p://airkusaja.blogspot.co.id/2012/ 01/produktifitas-efektivitasefisiensi-dan.html?=1, diakses 23 Juni 2017). 